\title{
Distribution and density of the bivalve Anomalocardia brasiliana in the estuarine region of Northeastern Brazil
}

\author{
A. M. L. Rodrigues Maia ${ }^{a}$, E. Medeiros ${ }^{a}$ and G. G. Henry-Silva ${ }^{a}$ \\ aLaboratório de Limnologia e Qualidade de Água - LIMNOAQUA, Departamento de Ciências Animais, \\ Universidade Federal Rural do Semiárido - UFERSA, BR 47, Km 110, Bairro Presidente Costa e Silva, \\ CEP 59625-900, Mossoró, RN, Brazil \\ *e-mail: allyssandramr@hotmail.com
}

Received: February 23, 2016 - Accepted: August 24, 2016 - Distributed: February 28, 2018

(With 7 figures)

\begin{abstract}
The objective of this study was to analyze the density and distribution of the bivalve Anomalocardia brasiliana in beaches in the estuarine region of the semiarid in Rio Grande do Norte State, Barra and Pernambuquinho (04 $56.978^{\circ}$ S and $37^{\circ} 08.961^{\prime} \mathrm{W}$ and $04^{\circ} 56.792^{\prime} \mathrm{S}$ and $37^{\circ} 09.375^{\prime} \mathrm{W}$, respectively). Samples were collected monthly during $37 \mathrm{months}$ using five transects (300 $\mathrm{m}$ long and $400 \mathrm{~m}$ apart) laid perpendicularly to the beach line toward the sea. Seven collection points, $50 \mathrm{~m}$ apart, were set in each transect, and shellfish and sediment samples were collected. Temperature and salinity were measured in each transect. The results showed a temperature variation of average values of $3{ }^{\circ} \mathrm{C}$; the greatest variation $\left(33.2^{\circ} \mathrm{C}\right)$ was observed in May of 2009 . The lowest average salinity values were observed between April and June of 2009 (5, 8.7, and 7.8, respectively). This fact was due to an atypical rainfall in the region, which resulted in a large freshwater inflow into the estuary; the average salinity values were about 40 in the remaining months. The highest precipitation values were observed in April/09, April/10, and April/11; the highest precipitation occurred in April/09 (316.3 mm). The lower average densities of $A$. brasiliana were observed in April and May/09 when compared to the other months; the lowest value was observed in April/09 (26 ind $\left./ \mathrm{m}^{2}\right)$. The highest densities occurred between November/10 and July/11, with values ranging from 70 to $322 \mathrm{ind} / \mathrm{m}^{2}$. The highest inflow of young individuals (lengths from 2 to $5 \mathrm{~mm}$ ) was observed between April and June of 2010 and on September/10 while the highest frequency of adults (from 20 to $25 \mathrm{~mm}$ ) occurred between December of 2010 and April of 2011. Hence, the results of this study show that in the months with the greatest rainfall, salinity and the average density of $A$. brasiliana showed the lowest values.
\end{abstract}

Keywords: density, mollusk, estuary, salinity, granulometry.

\section{Distribuição e densidade do bivalve Anomalocardia brasiliana em região estuarina do semiárido do Nordeste do Brasil}

\begin{abstract}
Resumo
O objetivo do trabalho foi analisar a densidade e distribuição do bivalve Anomalocardia brasiliana em praias de uma região estuarina do semiárido do Rio Grande do N (Barra - 0456,978'S, 3708,961' O e Pernambuquinho - 0456,792'S, $37^{\circ} 09,375^{\prime} \mathrm{O}$ ). As coletas foram realizadas durante 37 meses (abril/09 a abril/12). Mensamente foram dispostos cinco transectos (300 m de comprimento e distanciando $400 \mathrm{~m}$ entre si, perpendicularmente à linha da praia em direção ao mar. Em cada transecto foram definidos sete pontos de coletas com distância de $50 \mathrm{~m}$ entre si e coletadas amostras de moluscos e sedimento. Em cada transecto aferiu-se a temperatura e salinidade da água. Os resultados mostraram que houve uma variação dos valores médios de temperatura de $3^{\circ} \mathrm{C}$, sendo o mês de maio/09 ocorreu o maior valor dessa variável $\left(33,2^{\circ} \mathrm{C}\right)$. Quanto aos valores médios de salinidade, o período de abril a junho/09 apresentou-se os menores valores médio da salinidade (5, 8,7 e 7,8, respectivamente), tal fato ocorreu, devido a um período de chuvas atípicas na região, que resultou em um grande aporte de água doce no estuário, nos demais meses os valores médios da salinidade foram cerca de 40. Ao analisar a precipitação observou-se, que os maiores valores ocorreram nos meses de abril/09, abril/10 e abril/11, sendo que o maior valor da precipitação ocorreu no mês de abril/09 (316,3 mm). As densidades médias de $A$. brasiliana nos meses de abril e maio/09 foram menores quando comparadas as densidades médias dos demais meses, sendo que o menor valor foi observado no mês de abril $/ 09$ ( $\left.26 \mathrm{ind} / \mathrm{m}^{2}\right)$. As maiores densidades ocorreram no período de novembro/2010 a julho/2011, com valores variando de 70 a $322 \mathrm{ind} / \mathrm{m}^{2}$. No período de abril a junho de 2010 e no mês de setembro/10 foi observada uma maior entrada de indivíduos jovens (comprimentos entre 2 a $5 \mathrm{~mm}$ ), enquanto que durante o período de dezembro/2010 a abril/2011 ocorreu uma maior frequência de indivíduos adultos (entre 20 a $25 \mathrm{~mm}$ ). Assim verificou-se com o presente estudo que, nos meses que ocorreram maior precipitação, salinidade e densidade média de $A$. brasiliana foi menor.
\end{abstract}

Palavras-chave: densidade, molusco, estuário, salinidade, granulometria. 


\section{Introduction}

Studies on the population dynamics are of fundamental importance for effective fisheries management (Jennings et al., 1999; Nottingham and White, 2015) of mollusks in coastal and estuarine areas in Northeastern Brazil where the abundant presence of these organisms triggers fishing, generating jobs, income, and food (Rodrigues et al., 2013). The coastal area has an ecological, economic, and social value, and temporal variations in physical conditions such as climate and sea gradients. These variations directly influence ecosystem dynamics with respect to the distribution and densities of animal species, consequently affecting the local artisanal fisheries in several coastal communities (Silva et al., 2008; Gaspar et al., 2011; Guebert-Bartholo et al., 2011). These ecosystems tend to be highly productive and heterogeneous and, therefore, represent an excellent opportunity for studies on the population structure of euryhaline invertebrate species (Souza et al., 2014).

Biological (reproductive behavior and availability of food) and physical-chemical factors (hydrodynamics, particle size, the amount of organic matter, and precipitation) have been used to study the abundance and diversity patterns of mollusks (Soares-Gomes, et al., 2002; Soares-Gomes and Pires-Vanin, 2003; Oliveira et al., 2011). The ability of these organisms to survive physical and biological changes associated with environmental factors (tidal influence and substrate exposure) is displayed by temporal and spatial patterns of their distribution (Rodil et al., 2008; Veríssimo et al., 2013).

Artisanal exploitation of mollusks is a significant source of income and livelihood for traditional communities living in coastal areas (Castilla and Defeo, 2001). Bivalve fishing is well-documented in South American countries in studies of bivalve mollusks in the Pectinidae family, spots in Uruguay, Argentina, and Chile (Castilla and Defeo, 2001), and loco snails in Chile (Castilla and Defeo, 2001). In Brazil, studies on bivalve mollusks mainly involve spatial distribution and abundance (Araújo and Rocha-Barreira, 2004), population ecology (Boehs et al., 2008; Oliveira et al., 2011; Rodrigues et al., 2013), and efficiency and selectivity (Pezzuto et al., 2010).

Mollusk fishing is practiced along the entire Brazilian coast especially in the estuarine regions in the Northeastern semi-arid where several species of invertebrates, mainly the bivalve Anomalocardia brasiliana, are harvested (Rodrigues et al., 2013). This species has socio-economic importance and is marketed at different scales along the coast, especially in coastal communities that also use it in the family diet (Boehs et al., 2008). The exploitation of stocks of $A$. brasiliana is extensive and is depleting the current stocks in an uncontrolled way, which could compromise natural stocks (Rodrigues, 2009).

Understanding the aspects of population ecology of commercially important mollusk species, especially with respect to their distribution and density, aids in understanding fishery dynamics and providing the basis for monitoring and management activities. This study evaluated the distribution, density, spatial and temporal of the species A. brasiliana in the estuarine region.

\section{Material and Methods}

This study was carried out on beaches near the estuarine region of the Apodi/Mossoró River, between the Barra (04'56,978'S and $\left.37^{\circ} 08,961^{\prime} \mathrm{W}\right)$ and Pernambuquinho $\left(04^{\circ} 56,792^{\prime} \mathrm{S}\right.$ and $\left.37^{\circ} 09,375^{\prime} \mathrm{W}\right)$ beaches, in the municipality of Grossos-Rio Grande do Norte (Figure 1). The region's climate is semi-arid and affected by morphodynamic variables that act together to strongly influence depositional and erosional processes. Like other regions in the Northern coast of Rio Grande do Norte/NE, this is a highly dynamic coastal location that is constantly altered (Araújo et al., 2003).

The sampling campaign lasted 37 months (April/09 to April/12) and was carried out in five 300 meters long transects set in the intertidal zone at every 400 meters, $50 \mathrm{~m}$ apart from each other.

A. brasiliana individuals were collected with a circular tube measuring $15.7 \mathrm{~cm}$ in diameter and $12 \mathrm{~cm}$ in length; samples were placed in a $2 \mathrm{~mm}$ mesh sieve to remove excess sediment. Sediment samples were collected with a circular galvanic iron collector, $5.6 \mathrm{~cm}$ wide and $10 \mathrm{~cm}$ long. Mollusk and sediment samples were stored in plastic bags and identified by the sampling sites; the bags were stored in coolers in the field and frozen in the laboratory until analysis. Water temperature was measured with a multisensor for limnological variables; salinity was measured with the aid of a manual optical refractometer.

The counting and biometrics of live A. brasiliana individuals were performed with the aid of a caliper (at $0.01 \mathrm{~mm}$ precision) and samples were placed in a $2 \mathrm{~mm}$. Sediment samples were dried in an oven at $50^{\circ} \mathrm{C}$, and the granulometry analysis was subsequently performed using sieving techniques (Suguio, 1973).

The sediment samples were dried in an oven at $60^{\circ} \mathrm{C}$ for $48 \mathrm{~h}$, sieved $(2 ; 1 ; 0.5 ; 0.25 ; 0.125$; and $0.053 \mathrm{~mm}$ ), and $100 \mathrm{~g}$ samples were used for granulometry analysis. The sediment weight was measured after the sample processing through each sieve and classified as (i) gravel, (ii) coarse sand + medium sand, (iii) fine sand + very fine sand, and (iv) silt + clay. Water temperature was measured with the "Water Quality Checker" Model U-10 (Horiba), and salinity was measured with a manual optical refractometer. The region's rainfall data were obtained from the National Water Agency/ANA and used as the arithmetic mean of data from seven rainfall stations (Assu, Fazenda Angicos, Fazenda Poço verde, Governador Dix-Sept Rosado, Mossoró, Pedra de Abelhas, and Upanema) that are distributed along the hydrographic basin of the Apodi/Mossoró River. The correlation between the average density of $A$. brasiliana (individuals $/ \mathrm{m}^{2}$ ) and the study period was also analyzed on a quarterly scale.

The ANOVA parametric test was used to verify significant differences in the density of $A$. brasiliana. The tukey test was applied retrospectively when these differences were significant $(\mathrm{p}=0.05)$ when necessary. 


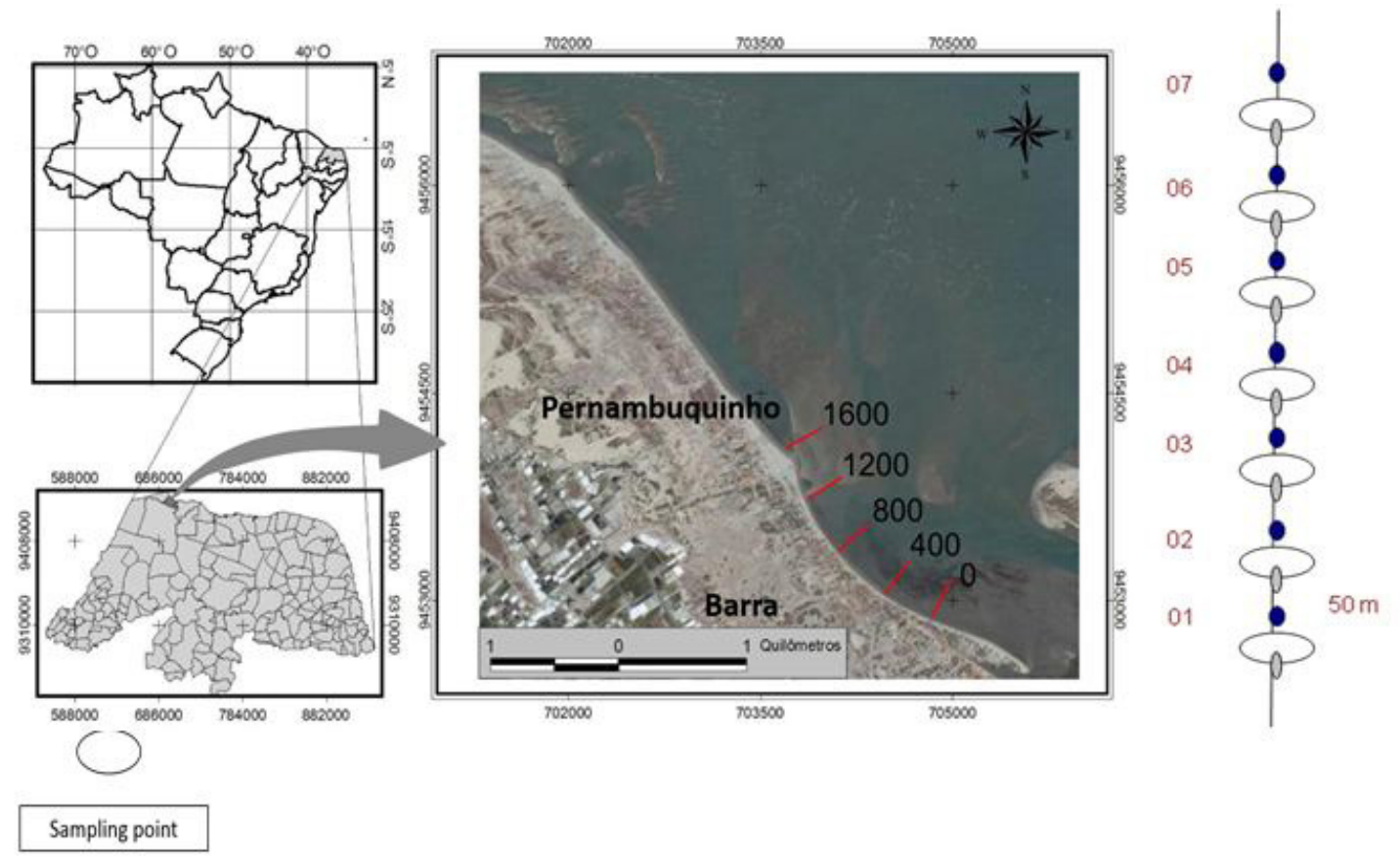

Sediment collected

Sampling A. brasiliana

Figure 1. A. brasiliana sampling sites in the estuarine region of the Apodi-Mossoró River. Sites at 0, 400, 800, 1200, and $1600 \mathrm{~m}$ from the estuary, between the Barra (04 $56,978^{\prime} \mathrm{S}$ and $\left.37^{\circ} 08,961^{\prime} \mathrm{W}\right)$ and Pernambuquinho $\left(04^{\circ} 56,792^{\prime} \mathrm{S}\right.$ and $\left.37^{\circ} 09,375^{\prime} \mathrm{W}\right)$ beaches and delineation of the transect with their respective collection points. Source: Google Earth (2015): adapted.

\section{Results}

A small variation in temperature values was observed; the highest amplitude $\left(33.2^{\circ} \mathrm{C}\right)$ was observed in May/09. The lowest salinity levels were observed between April and June/09 (5, 8.7, and 7.8, respectively). In January/2011, the salinity value was also low (25), however, increasing in the following months (Figure 2).

The highest amount of rainfall during the study period was observed in April/09 (316.3 mm) (Figure 3). Rainfall was reduced or did not occur in some months; however it was predominant in April and May. Rainfall values were low in September, October, and November during the study period.

The granulometric analysis showed high levels of (i) gravel, (ii) coarse sand + medium sand, (iii) fine sand + very fine sand, and (iv) silt + clay in the sediment in most months during the study (Figure 4). Furthermore, the presence of gravel was observed in almost every month. A higher density of $A$. brasiliana was observed in the months when the sediment contained greater amounts of the sand + very fine sand texture classes.

The average density of $A$. brasiliana was reduced in April and May/09; the lowest value was observed in April/09 (26 ind $\left./ \mathrm{m}^{2}\right)$. A variation in average density values was observed in the first collection months. The average density values were also low in August and October/2010 $\left(70 \mathrm{ind} / \mathrm{m}^{2}\right)$. High average density values were observed between November/2010 and July/2011; the highest average density values were observed in July/11 (322 ind $\left./ \mathrm{m}^{2}\right)$. Values tended to oscillate in October/November and December/2011 after the decline observed in August and September/2011.

The density values ranged from 335 to 786 individuals $/ \mathrm{m}^{2}$ before heavy rainfalls between March/07 and April/08. The overall density values ranged from 26 to 322 individuals $/ \mathrm{m}^{2}$ during the study period. A low average density of individuals of $A$. brasiliana was observed during periods of heavy rainfall. 


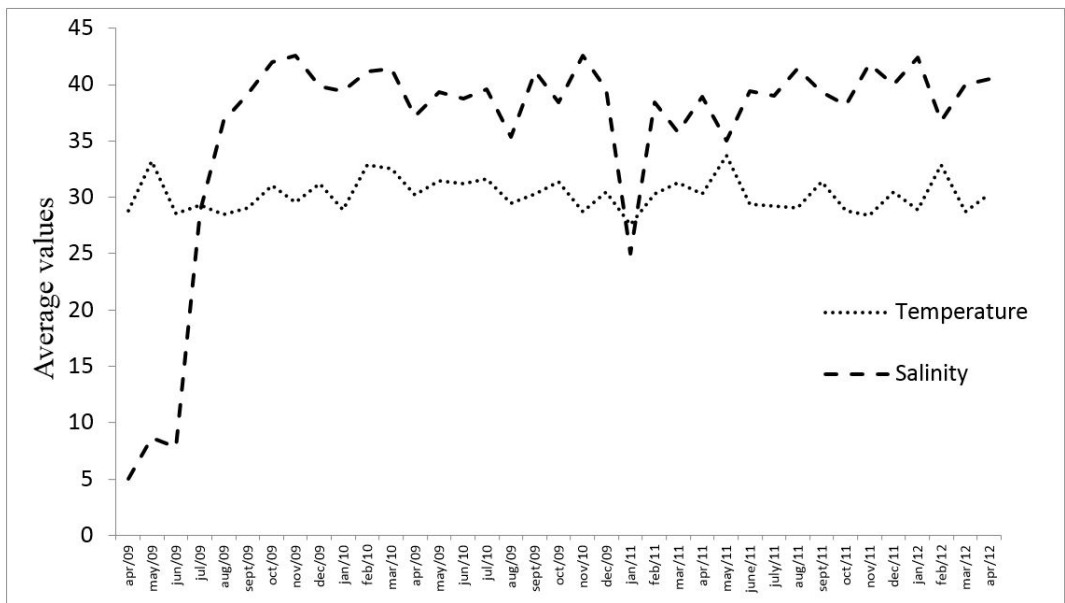

Figure 2. Average temperature $\left({ }^{\circ} \mathrm{C}\right)$ and salinity values.

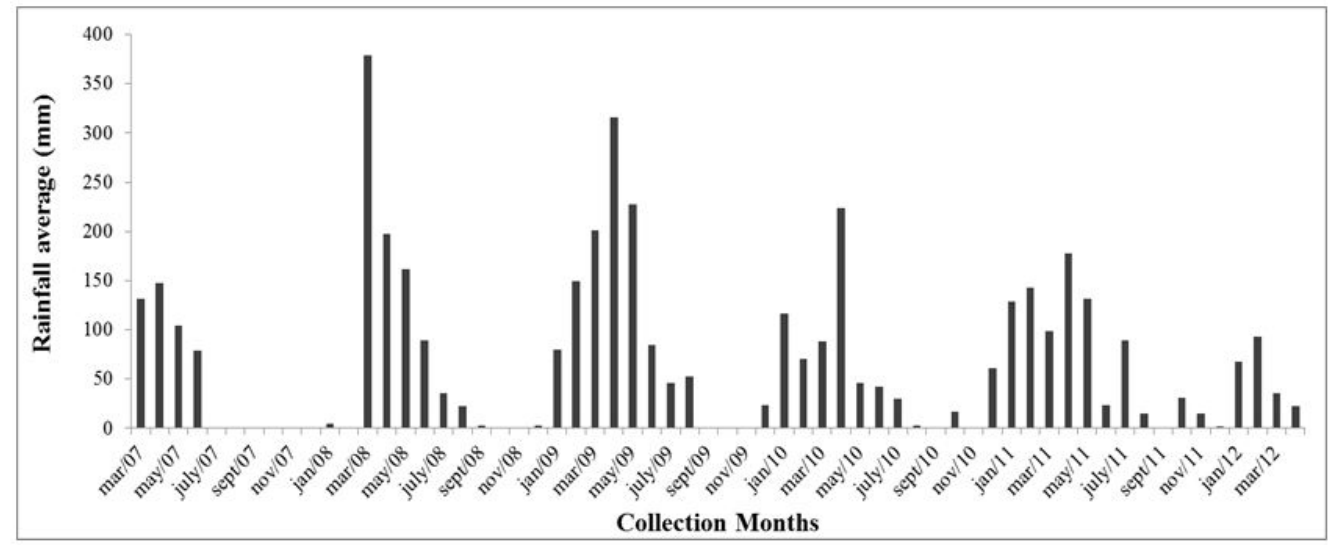

Figure 3. Rainfall average (mm) in the seven rainfall stations (Assu, Fazenda Angicos, Fazenda Poço verde, Governador Dix-Sept Rosado, Mossoró, Pedra de Abelhas e Upanema) in the Hydrographic Basin (estuarine region of the Apodi-Mossoró/RN River) between April/2009 and April/2012. Source: ANA (2015).

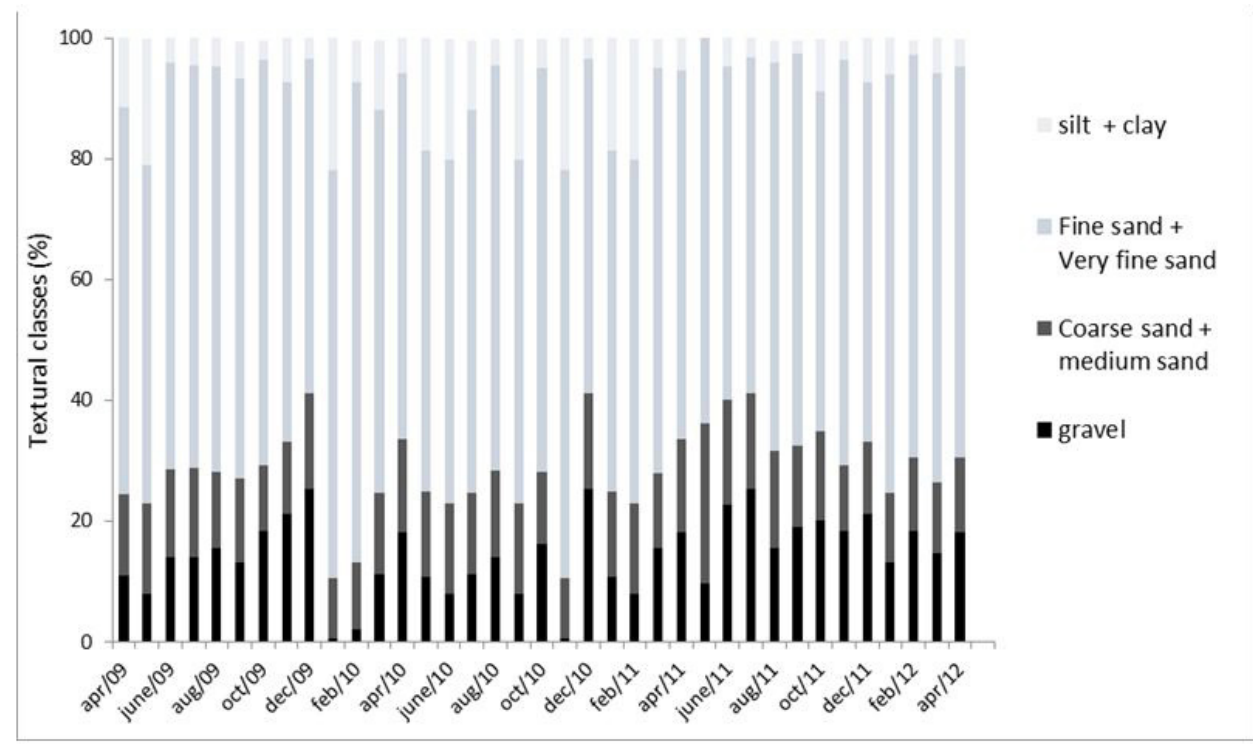

Figure 4. Frequency (\%) of sediment textural classes during the study period. 


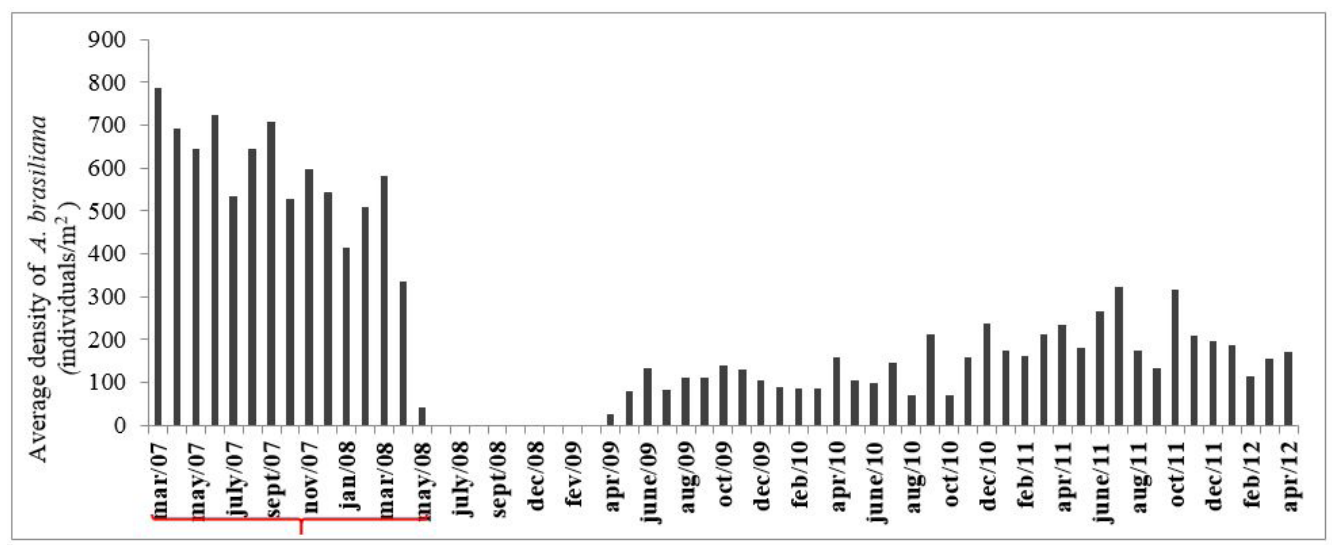

Figure 5. Average density values of individuals of $A$. brasiliana during the study period (April/09 to April/12). Highlighted figures refer to the average density of $A$. brasiliana from March/07 to May/08 in the Pernambuquinho beach (estuarine region of the Apodi-Mossoró River/RN) (Rodrigues et al., 2013).

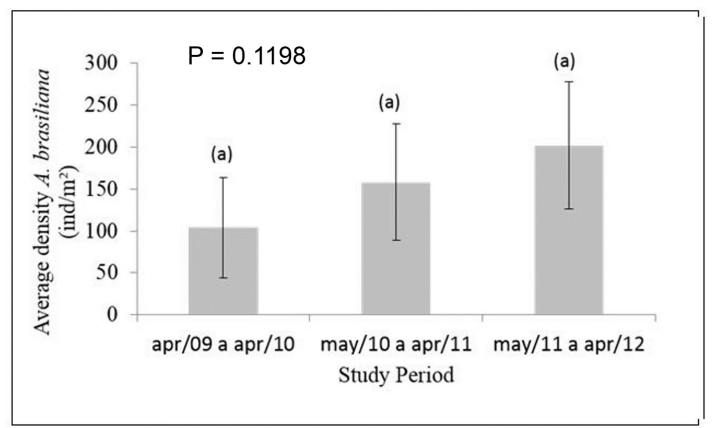

Figure 6. Average mean and standard deviation density of A. brasiliana (individuals $/ \mathrm{m}^{2}$ ) grouped in each year of the study period (April/09 to April/10, May/10 to April/11, and May/11 to April/12).

In general, an increase in this mollusk's density was observed during the study (Figure 5).

An increasing trend in A. brasiliana average densities was observed during the periods of April/09 to April/10, May/10 to April/11, and May/11 to April/12 when these periods were grouped in each study year, even though there is a tendency to increase during the observed period, there was no significant difference $A$. brasiliana density between the years ( 03 periods) $(\mathrm{p}=0.1198)$ (Figure 6$)$.

Individuals with lengths ranging from 1 to $29 \mathrm{~mm}$ were identified during the period from April/09 to April/12. Results show a greater population of young $A$. brasiliana individuals (sizes between 2-5 mm) between April and June/10 and in September/10. A higher frequency of adults (20 to $25 \mathrm{~mm}$ in length) was observed between December/2010 and April/2011. An input of young individuals was also observed between July and October/2011 (Figure 7).

\section{Discussion}

The results show a small variation in temperature values. This reduced temperature amplitude in the study area is probably related to the climate uniformity in the region, which is classified as semi-arid and very hot (IDEMA, 2008; Cruz-Neta and Henry-Silva, 2013; Rodrigues, 2009) found a similar pattern in this region. Conversely, studies conducted by Boehs and Absher and Cruz-Kaled (2008) in Paraná beaches, and Souza (2007) in Santa Catarina, report marked differences in the average temperatures during the year $\left(11\right.$ to $\left.30{ }^{\circ} \mathrm{C}\right)$ due to the existence of well-defined seasons. However, in our region, the semiarid climate may cause the reduced temperature variation.

The salinity values showed great variation during the study period; the lowest values were observed between April and June/09. The salinity values were low in January/2011 and increased in the following months. Similarly, in studies of population dynamics of the gastropod Neritina virginea in the estuary of the Apodi/Mossoró River, Cruz-Neta and Henry-Silva (2013) observed a wide range of salinity values during the same collection months as in our study. The highest values were observed between December/2007 and March/2008 and were probably related to increased river flow during the drought season. Corroborating data is reported by Rodrigues et al. (2010) who studied the biology and ecology of the bivalve $A$. brasiliana. They emphasized that there is an increased river flow in the drought season due to water input from salt washing activities in salt mines located in the estuary. This allows us to infer that, in the Study estuarine region, a greater fluctuation in salinity levels occur because there are periods of low rainfall and consequent drought.

The granulometry analysis showed a high percentage of very fine sand, and silt and clay, in almost every month of the study and all transect collected points. Rodrigues et al. (2013) report results similar to those observed in this study in the same species. The presence of these textural classes was related to the occurrence of $A$. brasiliana in the study region; these textural classes were predominant during the study period. Boehs et al. (2008) recorded the predominance of very fine sand and fine sand in the two intertidal shoals in Paranaguá Bay (Paraná) when analyzing the population ecology of A. brasiliana. Similarly, Beasley et al. (2005) 


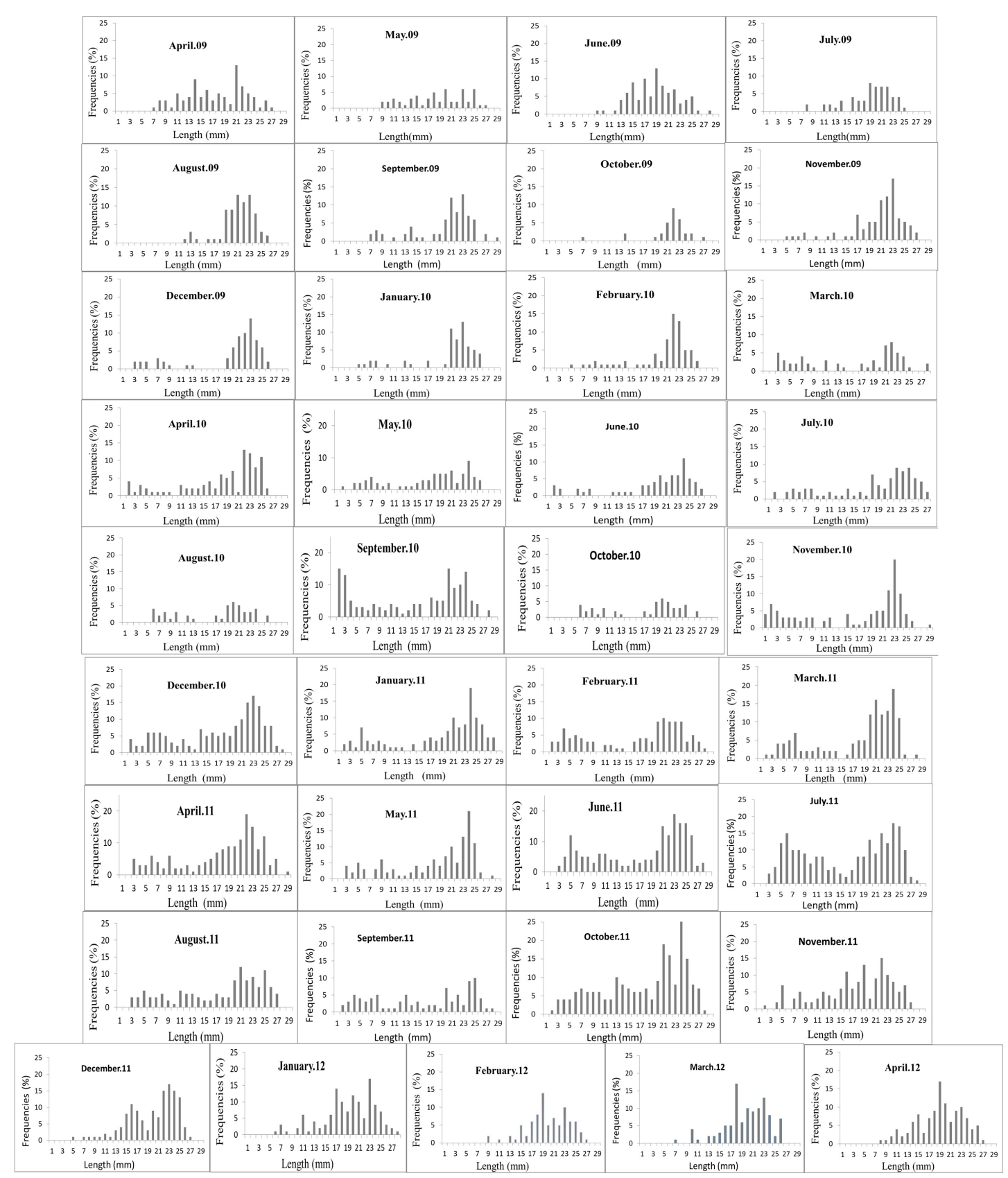

Figure 7. Distribution of length (mm) frequencies (\%) in the studied populations of A. brasiliana between April/2009 and April/2012.

analyzed the diversity and abundance of mollusks in coastal habitats in Pará and reported the occurrence of A. brasiliana in clay and sandy sediments. This allows us to infer that the species has a preference for this textural class and is able to live on this substrate spectrum in which the dynamics of their populations occurs.

The rainfall data in the studied region show that the highest value was observed in April/09 (316.3 mm). Rainfall was reduced or did not occur in some months. A predominance of rainfall was detected in April and May.
During the months of September, October, November, and December rainfall was virtually nonexistent or at a very low level. Similarly, Rodrigues et al. (2013) verified that there are two well-defined seasons in the Grossos/RN region, with the rainy season occurring between March and June/07 and a dry season occurring from July/07 to February/08, coinciding with the period of no rainfall observed in this study. Likewise, Belém et al. (2013), studying the distribution and density of the bivalve A. brasiliana in Rio Grande do Norte beaches, observed a 
higher rainfall and a longer duration of the rainy season that was probably caused by the weather phenomenon known as La Niña, which occurred in the region between 2008 and 2009, thus, causing high rainfall in the basin of the Apodi/Mossoró River. In a study with the bivalve Donax striatus in beaches near the estuary of the Apodi/Mossoró/RN River, Borges-Azevedo et al. (1990) found that the period of intense rainfall with a large loading of freshwater onto the beach prevented the settlement of young individuals and caused mortality in adult individuals. Likewise, in the present study, the average density of $A$. brasiliana was low in the months with increased rainfall. This allows us to infer that rainfall could be related to the presence or absence of this bivalve in this region.

The results for the average density of this species showed value variations in the studied period, ranging between months. The current data were compared with data from previous studies by Rodrigues et al. (2013) in the same region in a previous period (2007-2008). These authors found that the average density varied, especially in May/08 and during the period of abundant rainfall, which suggested that the decreased average abundance of A. brasiliana on the Barra and Pernambuquinho beaches resulted from a decreased salinity in the estuary. Increased salanity may have caused the death of these individuals. The values found by Rodrigues et al. (2013) are corroborated by the results reported by Boehs et al. (2008) in studies on the density of $A$. brasiliana in the Paranaguá Bay/PR showing that there were significant variations in density between sites and study period. Therefore, we can infer that the successful establishment of $A$. brasiliana in intertidal regions can be attributed to its rustic character, resistance to dissolved oxygen deficiency, and presence in sites with recognized variability, which are conditions generally observed in these environments.

The shortest length of $A$. brasiliana reported in the Brazilian literature is $10 \mathrm{~mm}$ (Lima et al., 2007). Some authors recommend $20 \mathrm{~mm}$ as the minimum size allowed for commercial fishing (Arruda-Soares et al., 1982; Araújo, 2001). Studies conducted in Southern Brazil have recommended that individuals shorter than $21 \mathrm{~mm}$ should not be captured (Schio and Pezzuto, 2008). In the estuarine region of the Northeastern semiarid, Rodrigues et al. (2013) found $A$. brasiliana with the minimum length of $1 \mathrm{~mm}$ while the maximum length was $28 \mathrm{~mm}$, which differs from the results reported by Soares et al. (1982) who observed individuals with $39 \mathrm{~mm}$ in the region of the Cardoso Island/SP. However, individuals with lengths ranging from 1 to $29 \mathrm{~mm}$ were identified between April/09 and April/12 in this study. An increased input of young individuals in populations of $A$. brasiliana was observed between April and June/10 in the study area suggesting a continuous recruitment with the presence of cohorts in November and December/09, January, February, and March/10, and from November/10 to January/11. Narchi (1976) observed similar results in a study on the reproduction of $A$. brasiliana in the Santos Bay/SP, also observing a continuous reproduction cycle in this species, especially in three months. $A$. brasiliana showed a maximum size of $28 \mathrm{~mm}$ and minimum of $2 \mathrm{~mm}$. It is important to highlight that the presence of a high density of larger mollusk individuals in a given population may cause a decrease in available space and food supply for young individuals. Consequently, recruitment success would be conditioned on the reduction of adult stocks (Monti et al., 1991). Thus, it can be inferred that the species may have continuous reproduction with recruitment peaks during the year.

The conclusions of this study are likely to assist in the monitoring of $A$. brasiliana stocks in the region. Thus, data on age structure, distribution, density, and spatial and temporal evaluation are important for managing stocks of A. brasiliana, especially due to its commercial interest and cultivation potential.

A small temperature variation was observed among the abiotic parameters, which is probably related to the climate uniformity in the region. However, a wide variation was observed in salinity values.

The granulometric analysis showed that the highest percentage of textural classes were represented by very fine sand and silt and clay. The presence of these classes was associated with the occurrence of $A$. brasiliana in the study region that can be probably explained by this mollusk's preference for this granulometry.

A seasonal variation was detected in the density of A. brasiliana. A high input of young individuals was detected in the studied populations of $A$. brasiliana, demonstrating continual recruitment.

The conclusions in this study might aid in the monitoring of bivalve $A$. brasiliana stocks in this region. Hence, data on population ecology are important for the management of $A$. brasiliana stocks especially because this is a species of commercial interest and with cultivation potential.

\section{References}

AGENCIA NACIONAL DAS ÁGUAS - ANA, 2015 [viewed 05 January 2015]. Available from: www.ana.gov.br

ARAÚJO, A.B., AMARO, V.E. and VITAL, H., 2003. Elaboração de mapas de vulnerabilidade ambiental na região de Grossos e Tibau do Norte, porção Setentrional do litoral do RN, a partir de produtos multitemporais de sensoriamento remoto. In: Anais XI Simpósio Brasileiro de Sensoriamento Remoto, 5-10 Abril 2003, Belo Horizonte, Brasil. São José dos Campos: INPE, pp. 1479- 1484.

ARAÚJO, C.M.M., 2001. Biologia reprodutiva do berbigão Anomalocardia brasiliana (Gmelin, 1791) (Mollusca, Bivalvia, Veneridae) na Reserva Extrativista Marinha de Pirajubaé. São Paulo: Universidade de São Paulo, 204 p. Tese de Doutorado em Biologia Genética.

ARAÚJO, M.L.R. and ROCHA-BARREIRA, C.A., 2004. Distribuição espacial de Anomalocardia brasiliana (GMELIN, 1791) (MOLLUSCA, BIVALVIA, VENERIDAE) na praia do canto da Barra, Fortim, Ceará, Brasil. Barreiros: CEPENE. 12 p.

ARRUDA-SOARES, H., SCHAEFFER-NOVELLI, Y. and MANDELLI, J., 1982. Anomalocardia brasiliana (Gmelin, 1791) bivalve comestível da região do Cardoso, Estado de São Paulo: 
aspectos biológicos de interesse para a pesca comercial. Boletim do Instituto de Pesca, vol. 9, pp. 21-38.

BEASLEY, C.R., FERNANDES, C.R., GOMES, C.P., BRITO, B.A., SANTOS, S.M.L. and TAGLIARO, C.H., 2005. Molluscan diversity and abundance among coastal habitats of northern Brazil. Ecotropica, vol. 11, pp. 9-20.

BELÉM, T.P., MOURA, R.S.T. and HENRY-SILVA, G.G., 2013. Distribuição e densidade do bivalve Anomalocardia brasiliana em praias do Rio Grande do Norte durante um período de pluviosidade atípica. Biotemas, vol. 26, no. 1, pp. 109-122. http:// dx.doi.org/10.5007/2175-7925.2013v26n1p109.

BOEHS, G., ABSHER, T.M. and CRUZ-KALED, A.C., 2008. Ecologia populacional de Anomalocardia brasiliana (Gmelin, 1791) (Bivalvia: Veneridae) na Baía de Paranaguá, Paraná, Brasil. Instituto Brasileira de Pesca, vol. 34, no. 2, pp. 259-270.

BORGES-AZEVEDO, C.M.S., MOURA NETO, E.L. and SILVA, J.S., 1990. Densidade populacional de Donax striatus Linnaeus (1767) (Bivalvia: Donacidae) na praia de Tibau, Grossos, Rio Grande do Norte. Caatinga, vol. 7, pp. 63-75.

CASTILLA, J.C. and DEFEO, O., 2001. Latin American benthic shellfisheries: emphasis on co-management and experimental practices. Reviews in Fish Biology and Fisheries, vol. 11, no. 1, pp. 1-30. http://dx.doi.org/10.1023/A:1014235924952.

CRUZ-NETA, C.P.E. and HENRY-SILVA, G.G., 2013. Aspectos da dinâmica populacional do Gastrópode Neritina virgínea em Região Estuarina do Rio Grande do Norte, Brasil. Boletim do Instituto de Pesca, vol. 39, pp. 1-14.

GASPAR, M.D., KLOKLER, D.M. and DEBLASIS, P., 2011. Traditional fishing, mollusk gathering, and the shell mound builders of Santa Catarina, Brazil. Journal of Ethnobiology, vol. 31, no. 2, pp. 188-212. http://dx.doi.org/10.2993/0278-0771-31.2.188.

GOOGLE EARTH, 2015 [viewed 10 February 2015]. Available from: https://www.google.com/earth/

GUEBERT-BARTHOLO, F.M., BARLETTA, M., COSTA, M.F., LUCENA, L.R. and PEREIRA DA SILVA, C., 2011. Fishery and the use of space in a tropical semi-arid estuarine region of Northeast Brazil: subsistence and overexploitation. Journal of Coastal Research, vol. 64, no. Special, pp. 398-402.

INSTITUTO DE DESENVOLVIMENTO SUSTENTÁVEL E MEIO AMBIENTE DO RIO GRANDE DO NORTE - IDEMA, 2008. Reserva de Desenvolvimento Sustentável Estadual Ponta do Tubarão: relatório técnico para o plano de manejo. Natal: IDEMA.

JENNINGS, S., REYNOLDS, J.D. and POLUNIN, N.V.C., 1999. Predicting the vulnerability of tropical reef fishes to exploitation with phylogenies and life histories. Conservation Biology, vol. 13, no. 6, pp. 1466-1475. http://dx.doi.org/10.1046/j.15231739.1999.98324.x.

LIMA, H.C., BARBOSA, J.M. and CORREIA, D.S., 2007. Extração de marisco por moradores da comunidade de BairaMar 2, Igarassu-PE. In: VII Jornada de Ensino, Pesquisa e Extensão - JEPEX, 10-14 Setembro 2007, Dois Irmãos, Brasil. Recife: Adaltech.

MONTI, D., FRENKIEL, L. and MOUËZA, M., 1991. Demography and growth of Anomalocardia brasiliana (Gmelin) (Bivalvia, Veneridae) in a mangrove, in Guadeloupe (French West Indies). Journal of Molluscan Studies, vol. 57, no. 2, pp. 249-257. http:// dx.doi.org/10.1093/mollus/57.2.249.
NARCHI, W., 1976. Ciclo anual da gametogênese de Anomalocardia brasiliana (Gmelin, 1791) (Mollusca: Bivalvia). Boletim Zoologia, vol. 1, no. 1, pp. 331-350.

NOTTINGHAM, C.D. and WHITE, W.L., 2015. Annual reproductive cycle and condition index of the New Zealand surf clam mactra murchisoni (Deshayes, 1854) (Bivalvia: Mactridae). Journal of Shellfish Research, vol. 34, no. 3, pp. 777-784.

OLIVEIRA, O., AMORIM, A., LAVANDER, H., PEIXOTO, S. and GALVEZ, A.O., 2011. Spatial and temporal distribution of the shellfish Anomalocardia brasiliana (Gmelin, 1791) on Mangue Seco beach, Pernambuco, Brazil. International Journal of Aquatic Science, vol. 2, pp. 1.

PEZZUTO, P.R., SCHIO, C. and ALMEIDA, T.C.M., 2010. Efficiency and selectivity of the Anomalocardia brasiliana (Mollusca: Veneridae) hand dredge used in southern Brasil. Journal of the Marine Biological Association of the United Kingdom, vol. 90, no. 7, pp. 1455-1464. http://dx.doi.org/10.1017/ S0025315410000317.

RODIL, I.F., CIVIDANES, S., LASTRA, M. and LÓPEZ, J., 2008. Seasonal variability in the vertical distribution of benthic Macrofauna and sedimentary organic matter in an estuarine beach (NW Spain). Estuaries and Coasts: J CERF, vol. 31, no. 2, pp. 382-395. http://dx.doi.org/10.1007/s12237-007-9017-4.

RODRIGUES, A.M.L., 2009. Ecologia populacional do molusco bivalve Anomalocardia brasiliana (GMELIN, 1791) (Bivalvia, Veneridae) em praias da região estuarina do rio Apodi/Mossoró$R N$. Mossoró: Universidade Federal Rural do Semiárido, $94 \mathrm{f}$. Dissertação de Mestrado em Ciência Animal.

RODRIGUES, A.M.L., AZEVEDO, C.M.B. and HENRY-SILVA, G.G., 2010. Aspectos da biologia e ecologia do molusco bivalve Anomalocardia brasiliana (Gmelin, 1791) (Bivalvia, Veneridae). Revista Brasileira de Biociências, vol. 8, no. 4, pp. 377-383.

RODRIGUES, A.M.L., BORGES-AZEVEDO, C.M., COSTA, R.S. and HENRY-SILVA, G.G., 2013. Population structure of the bivalve Anomalocardia brasiliana, (Gmelin, 1791) in the semi-arid estuarine region of northeastern Brazil. Brazilian Journal of Biology $=$ Revista Brasileira de Biologia, vol. 73, no. 4, pp. 15. PMid:24789399. http://dx.doi.org/10.1590/S151969842013000400019 .

SCHIO, C. and PEZZUTO, P.R., 2008. Seletividade da draga de mão (gancho) empregada na pescaria do berbigão Anomalocardia brasiliana na Reserva Extrativista Marinha de Pirajubaé-SC. In: Anais do IV Congresso Brasileiro de Oceanografia-CBO, 17 a 21 Maio 2010, Rio Grande, Brasil. CD-ROM.

SILVA, P.S.R., NEVES, L.P. and BEMVENUTI, C.E., 2008. Temporal variation of sandy beach macrofauna at two sites with distinct environmental conditions on cassino beach, extreme southern Brazil. Brazilian Journal of Oceanography, vol. 56, no. 4, pp. 257-270. http://dx.doi.org/10.1590/S1679-87592008000400001.

SOARES, H.A., SCHAEFFER-NOVELLI, Y. and MANDELLIJÙNIOR, J., 1982. Berbigão A. brasiliana (Gmelin, 1791), bivalve comestível da região da Ilha do Cardoso, Estado de São Paulo/ Brasil: Aspectos biológicos de interesse para a pesca comercial. Boletim do Instituto de Pesca, Sao Paulo, vol. 9, pp. 21-38.

SOARES-GOMES, A. and PIRES-VANIN, A.M.S., 2003. Padrões de abundância, riqueza e diversidade de moluscos bivalves na plataforma continental ao largo de Ubatuba, São Paulo, Brasil: uma comparação metodológica. Revista Brasileira de Zoologia, vol. 20, no. 4, pp. 717-725. http://dx.doi.org/10.1590/S010181752003000400027. 
SOARES-GOMES, A., PAIVA, P.C. and SUMIDA, P.Y.G., 2002. Bentos de sedimentos não-consolidados. In: R.C. PEREIRA and A. SOARES-GOMES. Biologia Marinha. Rio de Janeiro: Interciência, pp. 127-146.

SOUZA, D.S., 2007. Caracterização da pescaria do berbigão Anomalocardia brasiliana (GMELIN, 1791) (Mollusca:Bivalvia) na reserva extrativista Marinha do Pirajubaé (Florianópolis/SC): Subsídios para o Manejo. Itajaí: Universidade do Vale do Itajaí, 238 f. Dissertação de Mestrado em Ciência e Tecnologia Ambiental.

SOUZA, A.T., DIAS, E., MARQUES, J.C., ANTUNES, C. and MARTINS, I., 2014. Population structure, production and feeding habit of the sand goby Pomatoschistus minutis (Actinopterygii:
Gobiidae) in the Minho estuary (NW Iberian Peninsula). Environmental Biology of Fishes, vol. 98, no. 1, pp. 287-300. http://dx.doi.org/10.1007/s10641-014-0259-2.

SUGUIO, K., 1973. Introdução à sedimentologia. São Paulo: Edgard Blucher. 317 p.

VERÍSSIMO, H., LANE, M., PATRÍCIO, J., GAMITO, S. and MARQUES, J.C., 2013. Trends in water quality and subtidal benthic communities in a temperate estuary: is the response to restoration efforts hidden by climate variability and the Estuarine Quality Paradox? Ecological Indicators, vol. 24, pp. 56-67. http:// dx.doi.org/10.1016/j.ecolind.2012.05.028. 